Archimer, archive institutionnelle de l'Ifremer Volume 19, Number 5 / Oct. 2007: 549-556 http://www.ifremer.fr/docelec/

\title{
http://dx.doi.org/10.1007/s10811-007-9169-4
}

(C) 2007 Springer

The original publication is available at http://www.springerlink.com

\section{Diatom artificial medium (DAM): a new artificial medium for the diatom Haslea ostrearia and other marine microalgae}

\author{
Sindy Gagneux-Moreaux ${ }^{a^{*}}$, Christophe Moreau, \\ Jean-Louis Gonzalez ${ }^{b}$, Richard P. Cosson ${ }^{a}$ \\ a ISOMer, EA-2663, Université de Nantes, BP 92208, 44322 Nantes cedex 3, France \\ b IFREMER, Biogéochimie et Ecotoxicologie, BP 330, 83507 la Seyne sur Mer, France \\ *Author for correspondence: \\ phone $+(33) 251125691$ \\ fax $+(33) 251125668$ \\ e-mail: sindy.gagneux@univ-nantes.fr
}

\begin{abstract}
:
Artificial media are used in physiological studies of microalgae to maintain consistent conditions from one experiment to another and these media must be adapted to the needs of the organism studied. The artificial medium, in this case named diatom artificial medium (DAM), was designed to maintain long-term cultures of Haslea ostrearia and 19 other planktonic microalgae, and to allow physiological studies related to metal metabolism. The biomass and biochemical composition of $\mathrm{H}$. ostrearia grown in the DAM and in a modified Provasoli medium were compared to assess the suitability of this new artificial medium for the culture of this diatom. The DAM provided sufficient nutrients to allow $\mathrm{H}$. ostrearia to grow as efficiently as in the enriched seawater medium, without negative impact on metabolism. The DAM was tested with 19 other microalgae in order to widen its potential use, and 18 of the 19 showed a good adaptation to this medium. The chemical speciation of metals $(\mathrm{Cd}, \mathrm{Cu}, \mathrm{Pb}$, $\mathrm{Zn}$ ) was assessed using a speciation mathematical model. The presence of EDTA resulted in the total complexation of the trace metals implying that they were present in a sole chemical species in the DAM.
\end{abstract}

Keywords: Artificial culture medium - Microalgae - Diatom - Biochemical parameters - Metal speciation 


\section{Introduction}

34 Natural seawater enriched with nutrients, trace metals and vitamins is commonly used to maintain microalgal strains. The composition of seawater may be different for several sampling sites and periods, thereby leading to less reproducible and reliable experiments. Since 1890, media composed of seawater or seawater-like artificial solutions have been developed to keep axenic microalgal cultures under controlled laboratory conditions (Provasoli et al., 1957). Some artificial media were developed for the study of marine microalgal physiology (Berland et al., 1973; Carvalho and Malcata, 2000; Lane and Morel, 2000; Reinfelder et al., 2000). Moreover, the bioaccumulation of trace metals by microalgae was studied by using specific artificial media (Jensen et al., 1982; Price and Morel, 1990; Ahner et al., 1994; Yee and Morel, 1996; Yan and Pan, 2002). The advantages of such media are an accurate control of the concentration and speciation of metals in experimental conditions, and the opportunity to reproduce further experiments under identical conditions. Many studies about microalgae have focused on species largely used in aquaculture. The diatom Haslea ostrearia (Simonsen) is involved in the oyster greening, which consists in acquiring a blue green color on the gills and the labial palps (Ranson, 1937), increasing value of oyster products. Robert (1983) obtained long term productive cultures with this diatom after modifying the enriched seawater medium ES (Provasoli, 1968). In order to study some physiological aspects of this diatom, cultures were grown using artificial media. The artificial medium ESAW (Harrison et al., 1980; Berges et al., 2001) is based on an artificial seawater medium similar to that of Kester et al. (1967) enriched with Provasoli's ES solution. Cultures of H. ostrearia in ESAW showed cell deformation after several transfers (Mouget, pers. comm.). Moreau (1996) used the artificial Aquil medium (Morel et al., 1979; Price et al., 1988) and the f/50 medium derived from the enriched seawater $\mathrm{f} / 2$ medium (Guillard, 1982) for experiments involving cultures of $H$. ostrearia. Cultures appeared to be more productive in the $f / 50$ seawater medium than in the artificial medium, which implies specific nutritional

61 requirements for elements found in seawater but not in the artificial medium. Actually, the medium Aquil designed was tailored to study metal metabolism in microalgae, rather than a phytoplankton culturing medium in the first place (Morel et al., 1979). 
production by this diatom of a specific blue-green pigment, called "marennine", with short term cultures. This medium was very rich in nutrients and trace elements compared to other media (enriched natural water or artificial seawater). The aim of this study was to develop an artificial medium suitable to maintain long term productive cultures of $H$. ostrearia, and allowing physiological studies related to trace metal metabolism. For this reason, the artificial medium DAM (Diatom Artificial Medium) was developed after the Aquil model. Modifications were introduced according to literature data about $H$. ostrearia and artificial media, and assays based on the variation of the abundance of several elements (presence/absence, ratio). The ability of the DAM to sustain H. ostrearia was tested with a culture that lasted for two and a half months. For each growth cycle, the biomass and the total carbohydrate and protein contents were compared with those obtained with a strain grown in enriched seawater medium of ES type (Provasoli, 1968; Robert, 1983) usually used for $H$. ostrearia cultures (Robert, 1983; Lebeau et al., 2000; Tremblin et al., 2000; Robert et al., 2002). The DAM was also tested using nineteen different species of microalgae, essentially diatoms, through growth cycles, in order to widen its potential use. To understand metal/algal interactions, knowledge of speciation in the medium is essential. The chemical speciation of essential (copper and zinc) and non essential (cadmium and lead) metals was assessed using a speciation mathematical model.

\section{Methods}

\section{Composition of the media, DAM and ESI/3}

The composition of nutrient stock solutions and the DAM preparation protocol are given in Table 1. The trace element solution (III) was acidified in order to keep metals in solution and to prevent adsorption onto the flask. EDTA was added to the trace element solution before $\mathrm{FeCl}_{3}$ incorporation to avoid precipitation of ferric hydroxide (Morel et al., 1979). The $\mathrm{pH}$ of the medium was adjusted at 7.8 using a $1 \mathrm{M}$ hydrochloric acid solution. The filtered vitamin solution (IV) was added to the medium after being sterilized by filtration. This vitamin solution can be prepared in advance, fractioned and stored at $-18^{\circ} \mathrm{C}$. 
96 The composition of the modified enriched seawater medium ES1/3, derived from the ES

97 medium (Provasoli, 1968; Robert, 1983), is presented in Table 2 and is compared to the

Table 2

98 final concentration of elements in DAM and in the ES medium described by Provasoli

99 in 1968. The ES1/3 enrichment solution results in the third of the ES enrichment for a

100 main part of elements and the vitamin solution is that described by Guillard and Ryther

101 (1962). The optimal biomass attained in ES and ES1/3 was within the same range; but

102 ES1/3 appeared to be more suitable for H. ostrearia. Whereas Robert (1978) showed a

103 depletion of the culture maintained in ES medium with a decrease of the biomass and an

104 increase of the number of deformed cells, this author did not mention any depletion in

105 cultures of $H$. ostrearia performed in ES1/3.

106

107 Culture conditions

108 All the algal strains used in these experiments were provided by the Nantes Culture

109 Collection (WDCM 856, ISOMer, Université de Nantes, France). All the experiments

110 were carried out at $17^{\circ} \mathrm{C}$ under $80 \mu \mathrm{mol}$ photons. $\mathrm{m}^{-2} \cdot \mathrm{s}^{-1}$ irradiance with a $14: 10$ hour

111 photoperiod. The cultures were grown either in $250 \mathrm{~mL}$ flasks with $150 \mathrm{~mL}$ of sterilised

112 medium (Haslea crucigera (NCC 32), Haslea ostrearia (NCC 143), Odontella aurita

113 (NCC 87), Phaeodactylum tricornutum (NCC 45), Rhizosolenia setigera (NCC 81),

114 Skeletonema costatum (NCC 52), Thalassionema sp. (NCC 69) and Tetraselmis suecica

115 (NCC 62)) or in $100 \mathrm{~mL}$ tubes with $25 \mathrm{~mL}$ of DAM (all the other species tested in this

116 study). Each flask/tube was inoculated with the parent culture maintained in enriched

117 seawater at an initial concentration of 5000 cells.mL ${ }^{-1}$ (cycle $\mathrm{n}$ ). When the cultures

118 reached the stationary phase, the cells were transferred into a new flask containing fresh

119 medium at 5000 cells. $\mathrm{mL}^{-1}($ cycle $\mathrm{n}+1)$.

120 In order to test the capacity of the new medium to maintain the diatom H. ostrearia, a

121 strain was grown in the DAM and in the ES1/3 during five consecutive cycles. For each

122 culture condition, five replicates were realised.

123 The DAM was developed to grow H. ostrearia but its suitability for growing other

124 species of microalgae was tested to widen its potential use for physiological

125 experiments. Cultures in tubes or in flasks were run in a single example through 10 or 6

126 transfers depending on species. The experiment duration (4 months) allowed 10 cycles

127 to take place for cultures carried out in tubes while only 6 cycles were achieved by 
128 cultures carried out in flasks. The experiments included several repeated microscopic observations to identify shape modifications and to estimate number of cells per mL.

\section{Culture monitoring}

132 In order to compare the strain grown in the DAM with those grown in the modified ES

133 medium (ES1/3), growth rate and biochemical composition were determined for $H$.

134 ostrearia cultures. The cells were counted daily from the beginning of the exponential

135 phase to the stationary phase using a Nageotte hematocymeter. At this step, each culture

136 was filtered on Whatman GF-F membrane for analysis of a few biochemical parameters.

137 The physiological status of the microalgae was estimated using carbohydrate, pigment

138 (carotenoids and chlorophyll $a$ ) and protein concentrations determined by the

139 spectrophotometric methods of Dubois et al. (1956), Lorenzen (1967) and Lowry et al.

140 (1951) respectively.

\section{Metal speciation in the DAM}

143 A speciation mathematical model (MOCO) developed by IFREMER was used to

144 calculate essential metals $(\mathrm{Cu}$ and $\mathrm{Zn})$ speciation in the DAM. Development and

145 applications of this speciation model has already been described (Gonzalez et al., 2001a;

146 2001b; Laurier et al., 2003). The complexation constants used for the calculation of the

147 chemical species taken into account were compiled by Morel and Hering (1993).

148 Calculations were also performed with the addition of non-essential metals $(\mathrm{Cd}$ and $\mathrm{Pb})$

149 to determine their speciation in the DAM. Simulations were run with the initial element

150 concentrations at $\mathrm{pH} 7.8$, either with or without EDTA. Speciation of EDTA was

151 determined and the competition of metals with $\mathrm{Ca}^{2+}$ and $\mathrm{Mg}^{2+}$ was taken into account.

153 Statistical analysis

154 The normality and the homogeneity of variances being checked, the biomass and

155 biochemical parameters obtained for cultures grown in DAM and in enriched seawater

156 ES1/3 were compared using Student's t-test and one way analysis of variance

157 (ANOVA) with a significance level at $\alpha<0.05$ using Sigma Stat 2.0 (Jandel Scientific)

158 software. A posteriori tests (Tukey tests) were run with ANOVA data. 


\section{Growth experiments}

163 Fig. 1 shows the growth curves of $H$. ostrearia cultures carried out in the DAM and in

164 the ES1/3. For the five cycles presented in Fig. 1, the strain seems to grow better in the

165 DAM than in the modified ES medium, but the statistical analysis did not put forward

166 any significant difference with the exception of the third $(\mathrm{p}<0.001)$ and the fifth

167 transfers $(\mathrm{p}<0.001)$. The total carbohydrate and protein contents of $H$. ostrearia (Fig.

168 2) were stable with time for each tested medium (DAM and ES1/3). No significant

169 difference was shown between these contents at each sampling date. The carotenoid and

170 chlorophyll $a$ cell concentrations (Fig. 3$)$ were significantly higher (p < 0.05) in cells

171 grown in the DAM than those in cells grown in the ES1/3 since the second transfer. The

172 repeated microscopic observations did not reveal a significant proportion of deformed

173 cells in DAM compared to ES1/3.

175 Growth tests using various microalgae

Fig. 3

176 The results of the cultures carried out with 19 other microalgal species in DAM are

177 summarised in Table 3, which lists the species'names, the NCC strain codes and the

178 number of successful cycles.

179 All species kept in tubes grew successfully over ten cycles. Among the strains kept in

180 flasks, only Rhizosolenia setigera showed difficulties to grow in the DAM. Neither

181 shape modification nor growth decrease were noticed for the five other species kept in

182 flasks after 6 cycles achieved. Microscopic observations did not put forward any

183 modification of algal cells.

184

185 Chemical speciation of $\mathrm{Cd}, \mathrm{Cu}, \mathrm{Pb}$ and $\mathrm{Zn}$

186 Calculations of $\mathrm{Cd}, \mathrm{Cu}, \mathrm{Pb}$ and $\mathrm{Zn}$ speciation are presented in Table 4. Without EDTA,

187 each considered metal had specific affinities for inorganic ligands. The major amount of

188 copper was associated to carbonates (97\%) whereas zinc was mainly associated to

189 phosphates (90\%). The cadmium was mainly (90\%) associated to chlorides. Lead was

190 present as two major species, phosphates and chlorides for $50 \%$ and $40 \%$ of the total

191 lead respectively. 
192 The addition of EDTA resulted in a total complexation (100\%) of the considered metals

193 with this molecule. This complexation was assessed with concentration values from $10^{-8}$ mol. $\mathrm{L}^{-1}$ to $10^{-6}$ mol. $\mathrm{L}^{-1}$ of the different metals.

\section{Discussion}

197 The Diatom Artificial Medium DAM allows long term and productive culturing $H$.

198 ostrearia in controlled conditions. The cell shape and the global biochemical

199 composition appeared to be maintained after several transfers, which implies that DAM

200 contains the various elements in sufficient amounts for the optimal development of this

201 diatom. Requirement in silicon and copper appeared to be a main factor in the

202 development of the diatom. The slight increase in cell density observed from a transfer

203 to another could be explained by an acclimation of the strain to the medium supplies,

204 since carbohydrate and protein contents are similar for all transfers. Cultures of $H$.

205 ostrearia in larger volumes (10 L, $25 \mathrm{~L}$ and $200 \mathrm{~L})$ have been attempted at our

206 laboratory and the biomass achieved was as high as that obtained in enriched seawater

207 medium (cultures realised in ES1/3 and F/2 media, unpublished data). Consequently,

208 DAM has to be considered as a well-adapted artificial medium for $H$. ostrearia culture.

209 Furthermore, DAM allowed the culture of 18 species of microalgae through several

210 transfers, other than $H$. ostrearia, even though the artificial medium did not seem to be

211 convenient for the strain of Rhizosolenia setigera used in this experiment. It is

212 noteworthy that this diatom did not grow either in Aquil beyond 3 transfers (Morel et

213 al., 1979).

214 The speciation model showed that, in the absence of EDTA in DAM, the speciation of

215 the considered metals was similar to that reported for seawater (Florence, 1982;

216 Fernando, 1995, Stumm and Morgan, 1996). The presence of EDTA resulted in the

217 complexation of metals from low concentrations (encountered in natural ecosystems) to

218 higher concentrations (used in experimental studies). A low bioavailability of metals

219 decreases their direct toxicity. Using an adapted ratio of EDTA/metals, it is possible to

220 control the amount of metals bioavailable to microalgae and to mimic the low

221 concentrations found in natural environments. Moreover, when EDTA was not added to

222 DAM, the four tested metals were presented as various chemical species, whereas, in

223 EDTA-added DAM, these metals were essentially in a sole species. The interaction 
224 metals/microalgae is, thus, dependant on the dissociation constants of the complexes

225 EDTA-metals.

226 In conclusion, the medium DAM can be used for growing various microalgae in

227 medium term and for studying metal impact on the physiology of these microalgae.

228 Using this artificial medium would allow to study, in controlled conditions, the potential

229 bioaccumulation of metals in H. ostrearia (absorption and adsorption of metals,

230 kinetics) and to evaluate their impact on the growth and the culture quality.

231

232 Acknowledgements

233 We want to acknowledge the Region Pays de la Loire for the attribution of a fellowship 234 to S. G.-M.

235 Thanks are due to J.-L. Mouget for our discussions and to J. Kojadinovic for the

236 linguistic revision of the manuscript.

237

238 References

239

240 Ahner BA, Price NM, Morel FMM (1994) Phytochelatin production by marine

241 phytoplankton at low free metal ion concentrations: laboratory studies and field data

242 from Massachussets Bay. Proc Natl Acad Sci U.S.A. 91: 8433-8436

243 Berges JA, Franklin DJ, Harrison PJ (2001) Evolution of an artificial seawater medium:

244 improvements in enriched seawater, artificial water over the last two decades. J Phycol

$245 \quad 37: 1138-1145$

246 Berland BR, Bonin DJ, Maestrini SY, Pointier JP (1973) Etude de la fertilité des eaux

247 marines au moyen de tests biologiques effectués avec des cultures d'algues. III.

248 Réponses de la diatomée Skeletonema costatum à différentes concentrations d'éléments

249 nutritifs. Int Rev gesamten Hydrobiol 58: 401-416

250 Carvalho AP, Malcata FX (2000) Effect of culture media on production of

251 polyunsaturated fatty acids by Pavlova lutheri. Cryptogam, Algol 21: 59-71

252 Dubois F, Gilles KA, Hamilton JK, Rebers PA, Smith F (1956) Colorimetric method for

253 determination of sugar and related substances. Anal Chem 28: 350-356

254 Fernando Q (1995) Metal speciation in environmental and biological systems. Environ

255 Health Perspec 103: 13-16 
256 Florence TM (1982) The speciation of trace elements in waters. Talanta 29: 345-364

257 Gonzalez JL, Dange C, Thouvenin B (2001a) Spéciation des contaminants métalliques

258 en milieu estuarien : Intérêt de la modélisation et application au cadmium. Hydroecol

259 appl 13: 37-55

260 Gonzalez JL, Thouvenin B, Dange C, Fiandrino A, Chiffoleau JF (2001b) Modelling of

261 Cd speciation and dynamics in the Seine estuary (France). Estuaries 24: 1041-1055

262 Guillard RRL, Ryther JH (1962) Studies of marine planktonic diatoms. I. Cyclotella

263 nana Hustedt and Detonula confervacea (Cleve) Gran. Can J Microbiol 8: 229-239

264 Guillard RRL (ed) (1982) Culture of phytoplancton for feeding marine invertebrates.

265 Plenum Press, New-York

266 Harrison PJ, Waters EE, Taylor FJR (1980) A broad spectrum artificial medium for

267 coastal and open ocean phytoplankton. J Phycol 16: 28-35

268 Jensen TE, Rachlin JW, Jani V, Warkentine B (1982) An X-ray energy dispersive study

269 of cellular compartmentalization of lead and zinc in Chlorella saccharophila

270 (Chlorophyta), Navicula incerta and Nitzschia closterium (Bacillariophyta). Environ

271 exp Bot 22: 319-328

272 Kester DR, Duedall IW, Connors DN, Pytkowicz RM (1967) Preparation of artificial

273 seawater. Limnol Oceanogr 12: 176-179

274 Lane TW, Morel FMM (2000) Regulation of carbonic anhydrase expression by zinc,

275 cobalt and carbon dioxide in the marine diatom Thalassiosira weissflogii. Plant physiol

276 123: 345-352

277 Laurier FJG, Cossa D, Gonzalez JL, Breviere E, Sarazin G (2003) Mercury

278 transformations and exchanges in a high turbidity estuary: the role of organic matter and

279 amorphous oxyhydroxides. Geochim Cosmochim Acta 67: 3329-3345

280 Lebeau T, Gaudin P, Junter G-A, Mignot L, Robert J-M (2000) Continuous marennin

281 production by agar-entrapped Haslea ostrearia using a tubular photobioreactor with

282 internal illumination. Appl Microbiol Biotechnol 54: 634-640

283 Lorenzen CJ (1967) Determination of chlorophyll and pheopigments:

284 spectrophotometric equations. Limnol Oceanogr 12: 343-346

285 Lowry GH, Rosebrough NJ, Faar AL, Randall RJ (1951) Protein measurement with the

286 Folin phenol reagent. J Biol Chem 193: 265-275 
287 Moreau C (1996) Des eaux souterraines salées en Baie de Bourgneuf pour la production 288 de microalgues en aquaculture : l'azote ammoniacal, le fer et le manganèse dissous, 289 causes de la variabilité de la fertilité potentielle pour trois diatomées-tests. Thèse de 290 doctorat, Université de Nantes

291 Morel FMM and Hering JG (eds) (1993) Principles and applications of aquatic

292 chemistry. A Wiley Interscience publication. Wiley and sons, New York

293 Morel FMM, Rueter JG, Anderson DM, Guillard RRL (1979) Aquil: a chemically

294 defined phytoplankton culture medium for trace metals studies. J Phycol 15: 135-141

295 Neuville D, Daste P (1971) Observation concernant la production de pigment bleu par

296 la Diatomée Navicula ostrearia (Gaillon) Bory maintenue en culture unicellulaire sur un

297 milieu synthétique. C r Acad Sci Paris (Ser. D) 272: 2232-2234

298 Price NM, Harrison GI, Hering JG, Hudson RJ, Nirel PMV, Palenik B, Morel FMM

299 (1988) Preparation and chemistry of the artificial algal culture medium Aquil. Biol

300 Oceanogr 6: 443-461

301 Price NM, Morel FMM (1990) Cadmium and cobalt substitution for zinc in a marine 302 diatom. Nature 344: 658-660

303 Provasoli I, McLaughlin JJA, Droop MR (1957) The development of artificial media for 304 marine algae. Arch Mikrobiol 25: 392-428

305 Provasoli L (1968) Media and prospect for the cultivation of marine algae. In Watanabe,

306 A. and Hattori, A. (eds), Cultures and Collection of algae. Proc. USA, Japan Conf.

307 Hakone, sept. 1966. Jap Soc Plant Physiol 63-75

308 Ranson G (1937) Le verdissement des huîtres. Sciences 8: 13-24.

309 Reinfelder JR, Kraepiel AML, Morel FMM (2000) Unicellular $C_{4}$ photosynthesis in a

310 marine diatom. Nature 407: 996-999

311 Robert J-M (1978) Variations biométriques de l'algue Navicula ostrearia Bory

312 (Diatomée pennée) en culture. Bull - Soc phycol Fr 23: 38-44

313 Robert J-M (1983) Fertilité des eaux des claires ostréicoles et verdissement : utilisation

314 de l'azote par les diatomées dominantes. Thèse de Doctorat d'Etat es Sciences

315 biologiques, Université de Nantes

316 Robert J-M, Morançais M, Pradier E, Mouget J-L, Tremblin G (2002) Extraction and

317 quantitative analysis of the blue-green pigment "marennine" synthesized by the diatom

318 Haslea ostrearia. J appl Phycol 14: 299-305 
319 Stumm W, Morgan J J (eds) (1996) Aquatic chemistry. Chemical equilibria and rates in 320 natural waters, Third edition. Wiley and sons, New-York

321 Tremblin G, Cannuel R, Mouget J-L, Rech M, Robert J-M (2000) Change in light

322 quality due to a green pigment, marennine, released in oyster-ponds: effects on growth

323 and photosynthesis in two diatoms, Haslea ostreria and Skeletonema costatum. J appl

324 Phycol 12: 557-566

325 Yan H, Pan G (2002) Toxicity and bioaccumulation of copper in three green microalgal 326 species. Chemosphere 49: 471-476

327 Yee D, Morel FMM (1996) In vivo substitution of zinc by cobalt in carbonic anhydrase

328 of a marine diatom. Limnol Oceanogr 41: 573-577 
329 Figure legends

330

331 Fig. 1 Growth curves of Haslea ostrearia maintained for two and a half months in the Diatom Artificial Medium $(\bullet)$ and in the enriched seawater medium ES1/3 ( X ). Mean \pm standard deviation.

334

335

Fig. 2

Concentrations in carbohydrates and proteins per cell for culture of Haslea ostrearia maintained for two and a half months in the Diatom Artificial Medium and in the enriched seawater medium ES1/3. Mean \pm standard deviation. Artificial Medium and in the enriched seawater medium ES1/3. Mean \pm standard deviation. 


\begin{tabular}{lr}
\hline \hline Composition of stock solutions & \\
\hline Solution I: Ion solution & 1 liter \\
$\mathrm{H}_{3} \mathrm{BO}_{3}$ & $1.50 \mathrm{~g}$ \\
$\mathrm{KBr}$ & $5.00 \mathrm{~g}$ \\
$\mathrm{KCl}$ & $35.00 \mathrm{~g}$ \\
$\mathrm{NaF}$ & $0.15 \mathrm{~g}$ \\
$\mathrm{NaHCO}$ & $10.00 \mathrm{~g}$ \\
$\mathrm{SrCl}_{2}-6 \mathrm{H}_{2} \mathrm{O}$ & $0.85 \mathrm{~g}$
\end{tabular}

\begin{tabular}{|c|c|}
\hline $\begin{array}{l}\text { Solution II : Nutrients (Three different solutions } \\
\text { are prepared and stored at } 6^{\circ} \mathrm{C} \text { ) }\end{array}$ & 1 liter of each solution \\
\hline $\mathrm{NaH}_{2} \mathrm{PO}_{4}-\mathrm{H}_{2} \mathrm{O}$ & $1.38 \mathrm{~g}$ \\
\hline $\mathrm{NaNO}_{3}$ & $25.50 \mathrm{~g}$ \\
\hline $\mathrm{Na}_{2} \mathrm{SiO}_{3}-9 \mathrm{H}_{2} \mathrm{O}$ & $28.40 \mathrm{~g}$ \\
\hline Solution III :Trace Elements (in $\mathrm{HNO}_{3} \mathrm{0.01M}$ ) & 1 liter \\
\hline $\mathrm{CoCl}_{2}-6 \mathrm{H}_{2} \mathrm{O}$ & $1 \mathrm{~mL}$ of a $10 \mathrm{~g} . \mathrm{L}^{-1}$ solution \\
\hline $\mathrm{CuSO}_{4}-5 \mathrm{H}_{2} \mathrm{O}$ & $1 \mathrm{~mL}$ of a 9.80 g.L $\mathrm{L}^{-1}$ solution \\
\hline $\mathrm{MnCl}_{2} 4 \mathrm{H}_{2} \mathrm{O}$ & $1 \mathrm{~mL}$ of a $180 \mathrm{~g} . \mathrm{L}^{-1}$ solution \\
\hline $\mathrm{Na}_{2} \mathrm{MoO}_{4} 2 \mathrm{H}_{2} \mathrm{O}$ & $1 \mathrm{~mL}$ of a $6.30 \mathrm{~g} . \mathrm{L}^{-1}$ solution \\
\hline $\mathrm{Na}_{2} \mathrm{SeO}_{3}-5 \mathrm{H}_{2} \mathrm{O}$ & $1 \mathrm{~mL}$ of a $0.85 \mathrm{~g} . \mathrm{L}^{-1}$ solution \\
\hline $\mathrm{NiCl}_{2}-6 \mathrm{H}_{2} \mathrm{O}$ & $1 \mathrm{~mL}$ of a $0.74 \mathrm{~g} . \mathrm{L}^{-1}$ solution \\
\hline $\mathrm{ZnSO}_{4}-7 \mathrm{H}_{2} \mathrm{O}$ & $1 \mathrm{~mL}$ of a $22 \mathrm{~g} . \mathrm{L}^{-1}$ solution \\
\hline $\mathrm{FeCl}_{3}-6 \mathrm{H}_{2} \mathrm{O}$ & $3.15 \mathrm{~g}$ \\
\hline $\mathrm{Na}_{2}$ EDTA- $2 \mathrm{H}_{2} \mathrm{O}$ & $4.36 \mathrm{~g}$ \\
\hline Solution IV: Vitamin solution (After sterilization) & 1 liter \\
\hline Biotin & $10 \mathrm{~mL}$ of a $0.1 \mathrm{~g} \cdot \mathrm{L}^{-1}$ solution \\
\hline Cyanocobalamin & $1 \mathrm{~mL}$ of a 1 g.. $\mathrm{L}^{-1}$ solution \\
\hline Thiamine-HCl & $0,20 \mathrm{~g}$ \\
\hline \multicolumn{2}{|l|}{ Composition of the DAM } \\
\hline \multicolumn{2}{|l|}{ Salts } \\
\hline $\mathrm{NaCl}$ & $20.570 \mathrm{~g}$ \\
\hline $\mathrm{Na}_{2} \mathrm{SO}_{4}$ & $3.067 \mathrm{~g}$ \\
\hline $\mathrm{CaCl}_{2}-2 \mathrm{H}_{2} \mathrm{O}$ & $1.150 \mathrm{~g}$ \\
\hline $\mathrm{MgCl}_{2}-6 \mathrm{H}_{2} \mathrm{O}$ & $11.100 \mathrm{~g}$ \\
\hline Solution I: Ion solution & $15 \mathrm{~mL}$ \\
\hline \multicolumn{2}{|l|}{ Solution II: Nutrients } \\
\hline $\mathrm{NaH}_{2} \mathrm{PO}_{4}-\mathrm{H}_{2} \mathrm{O}$ & $2 \mathrm{~mL}$ \\
\hline $\mathrm{NaNO}_{3}$ & $1 \mathrm{~mL}$ \\
\hline $\mathrm{Na}_{2} \mathrm{SiO}_{3}-9 \mathrm{H}_{2} \mathrm{O}$ & $2 \mathrm{~mL}$ \\
\hline Solution III: Trace Elements & $2 \mathrm{~mL}$ \\
\hline Solution IV: Vitamin solution (After sterilization) & $1 \mathrm{~mL}$ \\
\hline Deionised water & Fill up to 1 liter \\
\hline
\end{tabular}


1 Table 2 Final concentrations of elements in DAM, ES and ES1/3 media.

2

\begin{tabular}{|c|c|c|c|}
\hline & $\begin{array}{c}\text { DAM } \\
\begin{array}{c}\text { Final concentration } \\
\left(\text { mol. } L^{-1}\right)\end{array} \\
\end{array}$ & $\begin{array}{c}\text { ES (Provasoli, 1968) } \\
\text { Final concentration } \\
\left(\text { mol. } L^{-1}\right)\end{array}$ & $\begin{array}{c}\text { ES1/3 (Robert, 1983) } \\
\text { Final concentration } \\
\left(\text { mol. } \mathrm{L}^{-1}\right)\end{array}$ \\
\hline \multicolumn{4}{|l|}{ Salts } \\
\hline $\mathrm{NaCl}$ & $3.52 \times 10^{-1}$ & & \\
\hline $\mathrm{Na}_{2} \mathrm{SO}_{4}$ & $2.16 \times 10^{-2}$ & & \\
\hline $\mathrm{CaCl}_{2}-2 \mathrm{H}_{2} \mathrm{O}$ & $7.82 \times 10^{-3}$ & & \\
\hline $\mathrm{MgCl}_{2}-6 \mathrm{H}_{2} \mathrm{O}$ & $5.46 \times 10^{-2}$ & & \\
\hline \multicolumn{4}{|l|}{ Solution I :Ion solution } \\
\hline $\mathrm{H}_{3} \mathrm{BO}_{3}$ & $3.64 \times 10^{-4}$ & $9.22 \times 10^{-5}$ & $3.07 \times 10^{-5}$ \\
\hline $\mathrm{KBr}$ & $6.30 \times 10^{-4}$ & & \\
\hline $\mathrm{KCl}$ & $7.04 \times 10^{-3}$ & & \\
\hline $\mathrm{NaF}$ & $5.36 \times 10^{-5}$ & & \\
\hline $\mathrm{NaHCO}_{3}$ & $1.79 \times 10^{-3}$ & $9.52 \times 10^{-4}$ & $9.52 \times 10^{-4}$ \\
\hline $\mathrm{SrCl}_{2}-6 \mathrm{H}_{2} \mathrm{O}$ & $4.61 \times 10^{-5}$ & & \\
\hline \multicolumn{4}{|l|}{ Solution II :Nutrients } \\
\hline $\mathrm{NaH}_{2} \mathrm{PO}_{4}-\mathrm{H}_{2} \mathrm{O}$ & $2.00 \times 10^{-5}$ & & \\
\hline $\mathrm{Na}_{2}$ Glycerophosphate- $6 \mathrm{H}_{2} \mathrm{O}$ & & $4.63 \times 10^{-5}$ & $1.54 \times 10^{-5}$ \\
\hline $\mathrm{NaNO}_{3}$ & $3.00 \times 10^{-4}$ & $8.24 \times 10^{-4}$ & $2.75 \times 10^{-4}$ \\
\hline $\mathrm{Na}_{2} \mathrm{SiO}_{3}-9 \mathrm{H}_{2} \mathrm{O}$ & $2.00 \times 10^{-4}$ & $5.00 \times 10^{-5}$ & $5.00 \times 10^{-5}$ \\
\hline \multicolumn{4}{|l|}{ Solution $\quad$ III $\quad$ :Trace } \\
\hline $\mathrm{CoCl}_{2}-6 \mathrm{H}_{2} \mathrm{O}$ & $8.41 \times 10^{-8}$ & & \\
\hline $\mathrm{CoSO}_{4}-5 \mathrm{H}_{2} \mathrm{O}$ & & $8.54 \times 10^{-8}$ & $2.85 \times 10^{-4}$ \\
\hline $\mathrm{CuSO}_{4}-5 \mathrm{H}_{2} \mathrm{O}$ & $7.85 \times 10^{-8}$ & & \\
\hline $\mathrm{FeCl}_{3}-6 \mathrm{H}_{2} \mathrm{O}$ & $2.33 \times 10^{-5}$ & $9.06 \times 10^{-7}$ & $3.02 \times 10^{-7}$ \\
\hline $\mathrm{Fe}\left(\mathrm{NH}_{4}\right)_{2}\left(\mathrm{SO}_{4}\right)_{2}-6 \mathrm{H}_{2} \mathrm{O}$ & & $8.95 \times 10^{-6}$ & $2.98 \times 10^{-6}$ \\
\hline $\mathrm{MnCl}_{2}-4 \mathrm{H}_{2} \mathrm{O}$ & $1.82 \times 10^{-6}$ & & \\
\hline $\mathrm{MnSo}_{4}-4 \mathrm{H}_{2} \mathrm{O}$ & & $3.26 \times 10^{-6}$ & $1.09 \times 10^{-6}$ \\
\hline $\mathrm{Na}_{2} \mathrm{MoO}_{4} 2 \mathrm{H}_{2} \mathrm{O}$ & $5.21 \times 10^{-8}$ & & \\
\hline $\mathrm{Na}_{2} \mathrm{SeO}_{3}-5 \mathrm{H}_{2} \mathrm{O}$ & $6.46 \times 10^{-9}$ & & \\
\hline $\mathrm{NiCl}_{2}-6 \mathrm{H}_{2} \mathrm{O}$ & $6.30 \times 10^{-9}$ & & \\
\hline $\mathrm{ZnSO}_{4}-7 \mathrm{H}_{2} \mathrm{O}$ & $1.53 \times 10^{-7}$ & $3.83 \times 10^{-7}$ & $1.28 \times 10^{-7}$ \\
\hline $\mathrm{Na}_{2}$ EDTA-2 $\mathrm{H}_{2} \mathrm{O}$ & $2.34 \times 10^{-5}$ & $2.23 \times 10^{-4}$ & $7.43 \times 10^{-5}$ \\
\hline Solution IV: & & & \\
\hline Biotin & $4.09 \times 10^{-9}$ & $4.09 \times 10^{-9}$ & $8.19 \times 10^{-8}$ \\
\hline Cyanocobalamin & $7.38 \times 10^{-10}$ & $1.48 \times 10^{-9}$ & $2.95 \times 10^{-9}$ \\
\hline Thiamine-HCl & $5.93 \times 10^{-7}$ & $2.96 \times 10^{-7}$ & $2.96 \times 10^{-6}$ \\
\hline $\begin{array}{l}\text { Optimal Biomass Achieved } \\
\left(10^{3} \text { Cells. } \mathrm{mL}^{-1}\right)\end{array}$ & Present study & $\begin{array}{l}\quad 230-250 \\
\text { at long term, decrease } \\
\text { of the dividion rate of } \\
\text { the culture and } \\
\text { increase of the } \\
\text { deformed cell ratio }\end{array}$ & $\begin{array}{c}200-250 \\
\text { (Robert, } 1983 \text {, Present } \\
\text { study) }\end{array}$ \\
\hline
\end{tabular}


1 Table 3 Transfers of different microalgae in DAM (Grown in $25 \mathrm{~mL}$ tubes, 2 except species noted $(*)$ grown in $250 \mathrm{~mL}$ flasks)

3

\begin{tabular}{|c|c|c|}
\hline Species & Clone & $\begin{array}{c}\text { Successful } \\
\text { Transfers }\end{array}$ \\
\hline \multicolumn{3}{|l|}{ Bacillariophyceae } \\
\hline Amphora hyalina & NCC 1 D-Am.hy. & 10 \\
\hline Bacillaria paradoxa & NCC 6 D-Ba.pa. & 10 \\
\hline Chaetoceros sp. & NCC 8 D-Ch.sp. & 10 \\
\hline Coscinodiscus granii & NCC 11 D-Co.gr. & 10 \\
\hline Entomoneis alata & NCC 17 D-En.al. & 10 \\
\hline Haslea crucigera* & NCC 32 D-Ha.cr. & 6 \\
\hline Heliotheca thamesis & NCC 59 D-He.th. & 10 \\
\hline Navicula ramosissima & NCC 73 D-Na.ra. & 10 \\
\hline Nitzschia compressa & NCC 38 D-Ni.co. & 10 \\
\hline Odontella aurita* & NCC 87 D-Od.au. & 6 \\
\hline Phaeodactylum tricornutum* & NCC 45 D-Ph.tr. & 6 \\
\hline Pleurosigma intermedium & NCC 78 D-Ple.in. & 10 \\
\hline Rhizosolenia setigera* & NCC 81 D-Rh.se. & $2-\dagger$ \\
\hline Skeletonema costatum* & NCC 52 D-Sk.co.B2 & 6 \\
\hline Thalassionema sp.* & NCC 69 D-Thn.sp. & 6 \\
\hline \multicolumn{3}{|l|}{ Other microalgae } \\
\hline Dunaliella sp. & NCC 14 C-Du.sp. & 10 \\
\hline Isochrysis sp. & NCC 24 Pry-Is.sp. & 10 \\
\hline Porphyridium cruentum & NCC 49 R-Po.cr. & 10 \\
\hline Tetraselmis suecica* & NCC 62 Pra-Te.Su. & 10 \\
\hline
\end{tabular}

4 *cultures performed in flasks.

$5 \dagger$ †no algal growth after transfer 
1 Table 4 Calculations of metal speciation $(\mathrm{Cu}, \mathrm{Zn}, \mathrm{Cd}, \mathrm{Pb})$ in the artificial 2 medium DAM with and without presence of EDTA (in percentage of the total concentration; nc: non calculated)

4

\begin{tabular}{lrrrr}
\hline \hline Association metal-ligand $(\%)$ & $\mathrm{Cu}^{\mathrm{a}}$ & $\mathrm{Zn}^{\mathrm{a}}$ & $\mathrm{Cd}^{\mathrm{b}}$ & $\mathrm{Pb}^{\mathrm{b}}$ \\
\hline Without EDTA & & & & \\
Free metal $\left(\mathrm{M}^{\mathrm{n}+}\right)$ & 0.030 & 6.412 & 3.723 & 5.515 \\
Chloride $\left(4.8 \times 10^{-1}\right.$ mol. $\left.\mathrm{L}^{-1}\right)$ & 0.011 & 2.340 & 95.233 & 39.177 \\
Hydroxyde & 0.014 & 0.210 & 0.006 & 2.367 \\
Phosphate $\left(2 \times 10^{-5}\right.$ mol. $\left.\mathrm{L}^{-1}\right)$ & 2.643 & 89.889 & n.c. & 48.869 \\
Carbonate $\left(1.8 \times 10^{-3} \mathrm{~mol}^{-1}\right)$ & 97.293 & n.c. & n.c. & n.c. \\
Sulfate $\left(2.2 \times 10^{-2}\right.$ mol. $\left.\mathrm{L}^{-1}\right)$ & 0.009 & 1.149 & 1.037 & 4.072
\end{tabular}

With EDTA ${ }^{\mathrm{c}}$

EDTA

Other species

$\begin{array}{rrr}100 & 100 & 100\end{array} \quad \begin{array}{r}100 \\ <1 \times 10^{-8}\end{array} \quad<1 \times 10^{-8} \quad<1 \times 10^{-8} \quad<1 \times 10^{-8}$

5 a with concentrations of the artificial medium DAM: $[\mathrm{Cu}] 7.85 \times 10^{-8} \mathrm{~mol}^{-\mathrm{L}^{-1}}$ and $[\mathrm{Zn}]$

$6 \quad 1.53 \times 10^{-7} \mathrm{~mol} . \mathrm{L}^{-1}$

$7{ }^{\mathrm{b}}$ with an addition of $10^{-8}$ mol. $\mathrm{L}^{-1}$ of total cadmium and lead to the DAM

$8{ }^{c}$ major species of $\operatorname{EDTA}(\mathrm{Y}): \mathrm{HY}^{3-}(97.5 \%), \mathrm{H}_{2} \mathrm{Y}^{2-}(2.5 \%)$ 


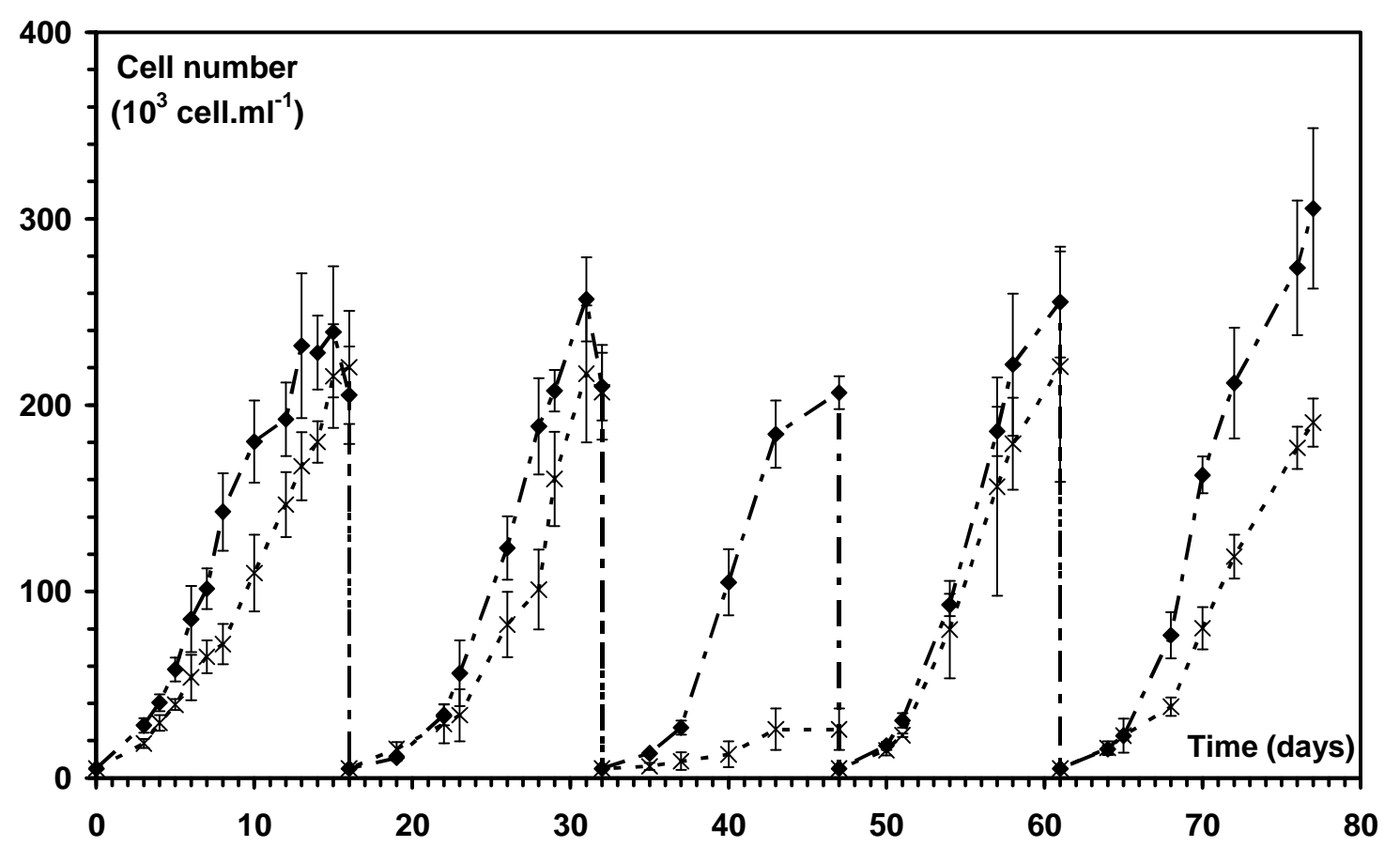

2

3 Fig. 1 Gagneux-Moreaux, Moreau, Gonzalez, Cosson 


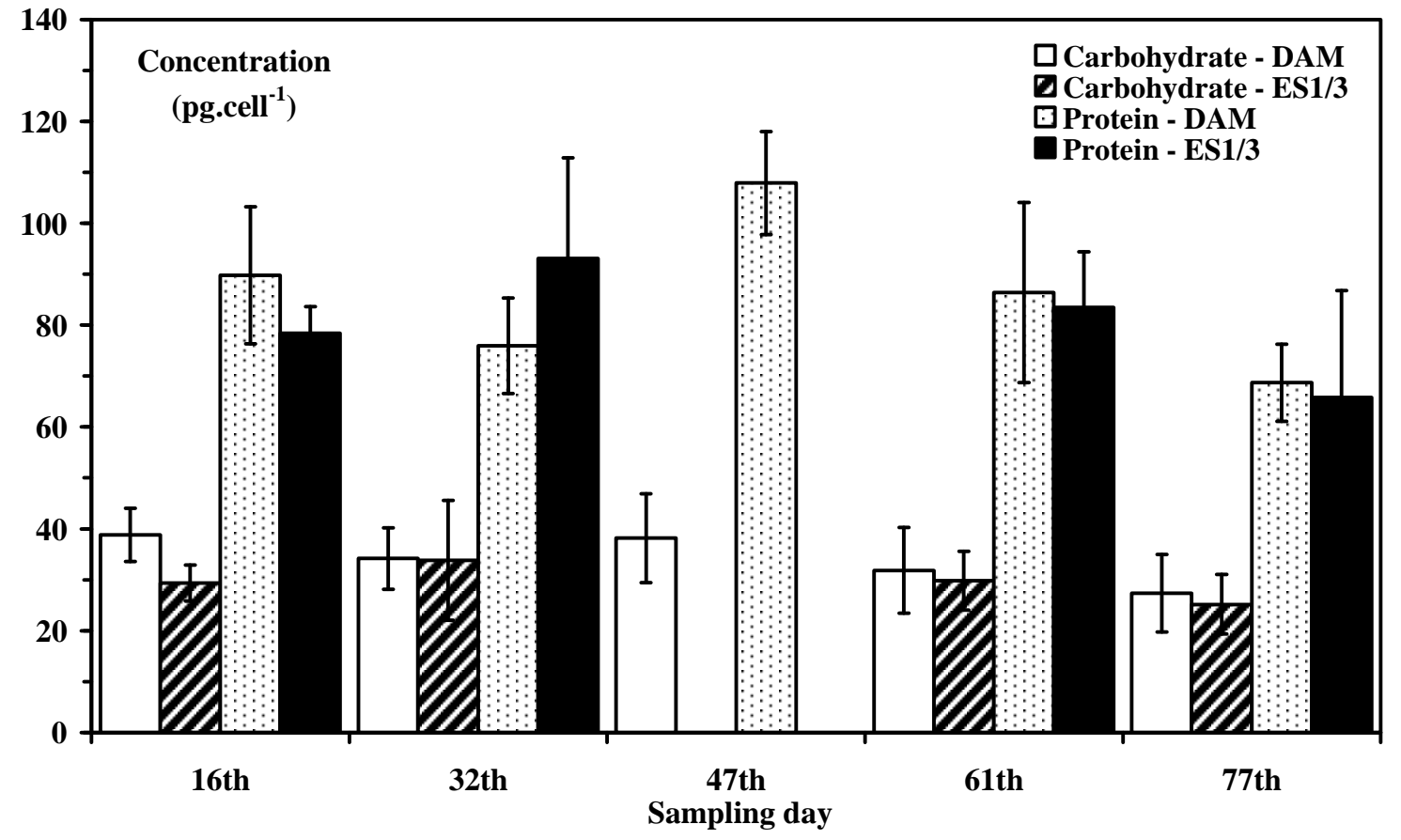

Fig. 2 Gagneux-Moreaux, Moreau, Gonzalez, Cosson 


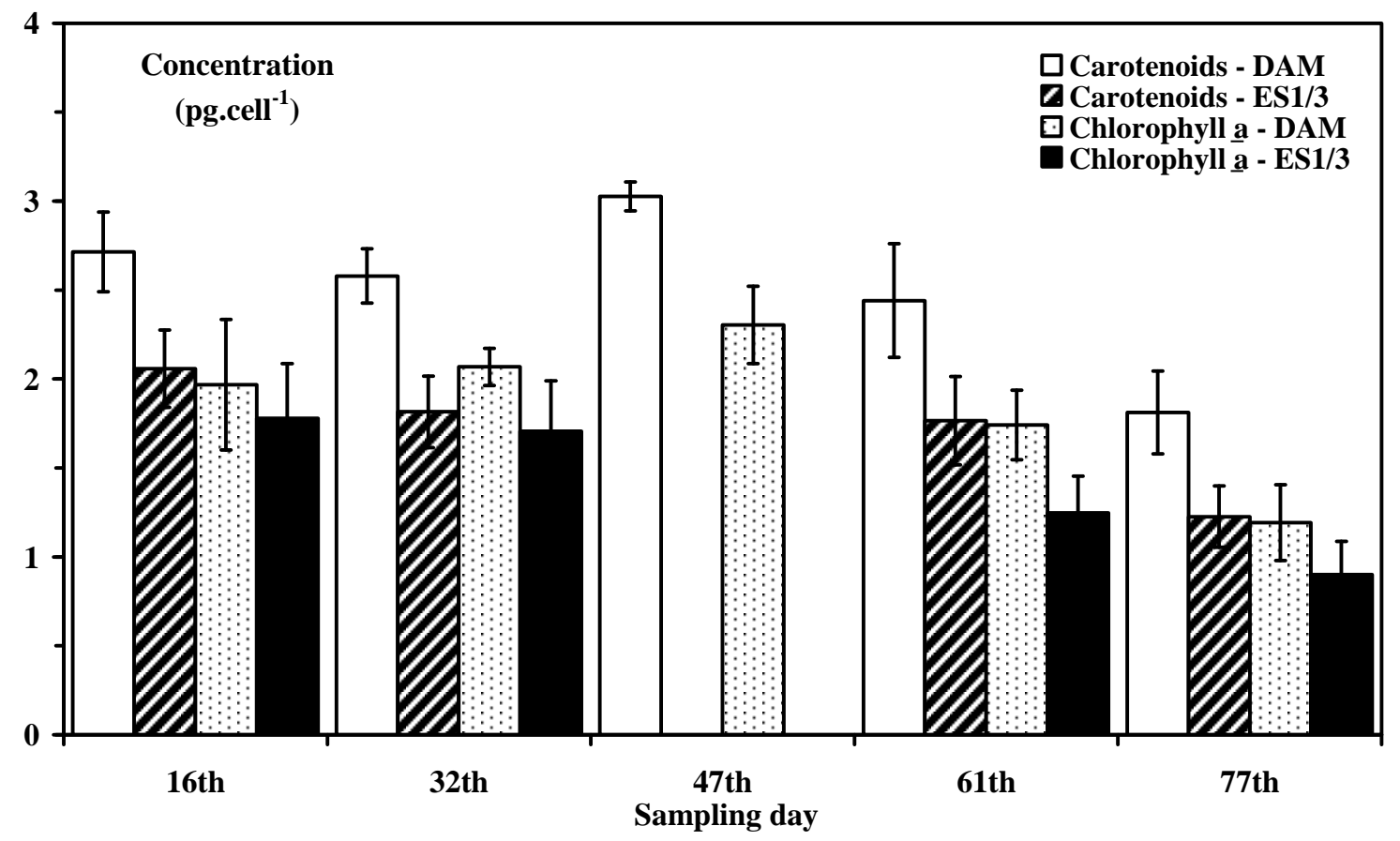

Fig. 3 Gagneux-Moreaux, Moreau, Gonzalez, Cosson 